\title{
Globalization and multi-level governance of environmental harm
}

Citation for published version (APA):

Faure, M. G. (2010). Globalization and multi-level governance of environmental harm. In M. Faure, \& A. V. D. Walt (Eds.), Globalization and Private Law (pp. 383-425). Edward Elgar Publishing. https://doi.org/10.4337/9781849805216.00024

Document status and date:

Published: 01/01/2010

DOI:

10.4337/9781849805216.00024

Document Version:

Publisher's PDF, also known as Version of record

Document license:

Taverne

Please check the document version of this publication:

- A submitted manuscript is the version of the article upon submission and before peer-review. There can be important differences between the submitted version and the official published version of record.

People interested in the research are advised to contact the author for the final version of the publication, or visit the DOI to the publisher's website.

- The final author version and the galley proof are versions of the publication after peer review.

- The final published version features the final layout of the paper including the volume, issue and page numbers.

Link to publication

\footnotetext{
General rights rights.

- You may freely distribute the URL identifying the publication in the public portal. please follow below link for the End User Agreement:

www.umlib.nl/taverne-license

Take down policy

If you believe that this document breaches copyright please contact us at:

repository@maastrichtuniversity.nl

providing details and we will investigate your claim.
}

Copyright and moral rights for the publications made accessible in the public portal are retained by the authors and/or other copyright owners and it is a condition of accessing publications that users recognise and abide by the legal requirements associated with these

- Users may download and print one copy of any publication from the public portal for the purpose of private study or research.

- You may not further distribute the material or use it for any profit-making activity or commercial gain

If the publication is distributed under the terms of Article $25 \mathrm{fa}$ of the Dutch Copyright Act, indicated by the "Taverne" license above, 


\title{
M-EPLI
}

MAASTRICHT EUROPEAN PRIVATE LAW INSTITUTE

WORKING PAPER No. 2011/20

\section{GLOBALIZATION AND MULTI-LEVEL GOVERNANCE OF ENVIRONMENTAL HARM}

Michael Faure

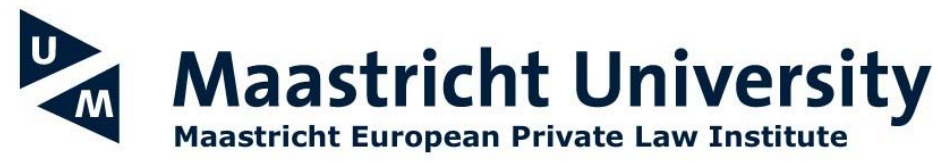

\author{
FACULTY OF LAW \\ MAASTRICHT UNIVERSITY
}

JUNE 2011

The paper can be downloaded without charge from the Social Science Research Network at http://www.ssrn.com 


\title{
GLOBALIZATION AND MULTI-LEVEL GOVERNANCE OF ENVIRONMENTAL HARM
}

\author{
Michael Faure \\ $\underline{\text { michael.faure@maastrichtuniversity.nl }}$
}

\begin{abstract}
This paper is a chapter in a book on globalization and private law and deals with the mutual influence of globalization on environmental issues. Both a positive as well as a normative analysis is provided. The paper discusses inter alia the question whether globalization necessarily leads to a lowering of environmental quality and whether it should lead to an argument in favour of centralization of decision making concerning environmental harm. Also, the contribution of environmental law to the globalization debate is discussed.
\end{abstract}

Keywords: globalization, transboundary pollution, environmental quality, race-to-thebottom, trade, environment, public participation, protectionism

Published in: GLOBALIZATION AND PRIVATE LAW, pp. 383-425, M. Faure \& A. van der Walt, eds., Cheltenham: Edward Elgar, 2010 


\section{Globalization and multi-level governance of environmental harm}

\section{Michael Faure}

\section{INTRODUCTION}

\subsection{Starting Point}

The starting point for most of the chapters in this book is that lawmaking, and more particularly the development of private law, poses specific challenges in the era of globalization. It is this particular influence of the broad globalization phenomenon on private lawmaking that has been the central focus of the contributions in this book. This chapter will take up the challenge to examine this relationship between globalization and (private) lawmaking as far as the area of environmental law is concerned. ${ }^{1}$

There are potentially so many interfaces between globalization and environmental problems that one could easily write an entire monograph simply dealing with this relationship. The aim of this chapter is, however, more modest. I will merely attempt to identify the influence of environmental issues on globalization and vice versa, from both a positive and a normative perspective. This will allow me to identify a few issues that play a role in this respect and to indicate a few areas where the relationship between globalization and environmental law could lead to tensions. ${ }^{2}$ Within the scope of this chapter it is not possible to even attempt to resolve these tensions. One can at most try to identify some core questions and analyse to what extent environmental issues pose problems or challenges for globalization that may be different from those in other areas discussed in this volume.

\footnotetext{
1 See on this topic also the challenging paper by Wirth (2007).

2 However, according to some authors these tensions are highly exaggerated. See for example Wirth (2007, p. 1): 'Pitting globalization and environment against each other as conflicting goals is a simplistic and self-defeating perspective.' Also Howse holds that it is at this moment no longer useful to discuss whether globalization as such is good or bad: 'This debate, I argue, is over, above all because the antiglobalizers have themselves gone global' (Howse 2008, p. 1529). See, however, for a different perspective the contributions in Speth (2003).
} 
The central issue discussed in this chapter is hence how an analysis and discussion of environmental pollution and the related environmental law and policy issues can contribute to a quest for the relationship between globalization and private law, which lies at the heart of the contributions to this volume.

\subsection{Challenges}

There is a broad literature on the relationship between globalization and specific environmental problems. In this respect, one can for example refer to the broad literature on sustainable development ${ }^{3}$ or one could focus on the question of how international law could be used as a remedy against transboundary environmental pollution ${ }^{4}$ or on the literature on multi-level governance and the environment. ${ }^{5}$ These and many other issues are debated under the heading of globalization and environmental problems. Some economists pay particular attention to the relationship between economic competitiveness and environmental issues ${ }^{6}$ or to the relationship between free trade and environmental protection. ${ }^{7}$

It is of course impossible within the scope of this chapter to discuss all of these issues in detail. Hence, a different approach will be followed. I will rather try to identify the various types of potential conflicts between environmental protection and globalization by structuring the various potential topics along two main lines of division (although I immediately admit that in some cases it is not so easy to sharply distinguish where a particular issue or conflict should best be categorized). A first dividing issue is whether the problem concerns the influence of environmental problems on globalization or whether it is rather the reverse - that globalization has a particular influence on environmental law and policy. A second dividing line would be to identify the positive analysis whereby one would examine or rather describe the mutual relationship between environmental pollution and globalization. This would be distinguished from the situation where a normative statement would be

3 See more particularly on the relationship between globalization and sustainable development Baker and McCormick (2004) and Martens and Zywietz (2006, pp. 331-50) as well as Martens (2007, pp. 39-47) and Sands (2000, pp. 369-409). And see the contributions in Bugge and Voigt (2008).

4 See for example Birnie and Boyle (2002) and Sands (2003). See also the contributions in Faure and Song (2008) and in Bratspies and Miller (2006).

5 See generally on multi-level governance de Prado (2007) and Follesdal et al. (2008) and see on multi-level governance and environmental issues especially the contributions in Winter (2006).

6 See more particularly Porter and Van den Linde (1995, pp. 97-118) and Copeland and Taylor (2004, pp. 7-71).

7 See for example Vogel (2004, pp. 231-2). 
formulated concerning this particular relationship. In the latter case, the analysis would involve arguing whether the influence of globalization on environmental issues is desirable or not. In order to be able to provide such a normative statement, one undoubtedly needs a point of reference.

To the extent that this chapter will provide such a normative indication concerning the relationship between environmental problems and globalization, the reference point used is usually the one provided by economics, namely efficiency. I consider the economic approach to law generally, and to environmental law and policy in particular, a very useful methodology not only to structure particular questions but also to provide an indication of the desirability of particular developments. ${ }^{8}$ With this, I of course do not argue that efficiency is the only criterion that should guide environmental policy. Other criteria such as the desire to provide a high level of environmental protection may also play a role at the policy level, for example to examine the influence of globalization on environmental issues. Still, in that particular case economic analysis remains useful. It will for example allow indicating whether the choice of a high level of environmental protection may come at a (too) high price.

Even though it may in some cases be artificial to separate particular issues along the lines suggested above, I will try to order the various questions that could arise along those lines merely because I hope it may provide a framework to structure the otherwise too complex and manifold questions. The structure is hence merely chosen for reasons of presentation, not always for contents.

This chapter will on the one hand discuss the relationship between globalization and environmental problems generally. However, since that may be slightly too ambitious and complex, the major focus will, within the general framework of this project, obviously be on the particular relationship between globalization and environmental law and policy. Given the general focus of the other chapters in this volume on the influence of globalization on private lawmaking, there will equally be a strong focus on private law. However, given the important influence of regulation in environmental law and policy, many issues will deal with environmental regulation as well as with private law.

\subsection{General Background}

The goal of this chapter is to contribute to the general aim of this book, being to identify particular challenges posed by globalization for environmental law

8 A summary of the economic approach to environmental law and policy can be found in Faure and Skogh (2003). 
and policy. Hence, some of the more general questions, also indicated in the introduction to this volume, concerning the relationship between globalization and private lawmaking will be analysed within the specific context of environmental problems.

One particular issue that will play a major role in the globalization debate generally and hence also for environmental problems is to what extent there is a 'lawmaking beyond the nation state'. The challenges posed by this multilevel governance lead to the institutional questions of who sets the agenda and who takes decisions on the appropriate remedies for (also transboundary) environmental harm. ${ }^{9}$ The general question, being to what extent a shift to higher levels of governance leads to increasing problems of accountability and legitimacy, will also be a crucial one in the environmental context. The goal of this chapter will be to identify the specific issues and topics that arise in that respect and perhaps to indicate in what direction solutions may be found.

An equally central focus of this chapter will be that, although many problems to be discussed in this contribution seem 'global' in the sense that, for example, lawmaking emerges from international organization or deals with transboundary environmental pollution, the problems often have effects for individuals in private legal relationships. It is more particularly this relationship between the various legal orders (international, regional (such as European), state and local levels) that poses interesting questions for the way environmental problems are dealt with in a specific context.

\subsection{Structure}

The remainder of this chapter is structured as follows: after this introduction, the influence of environmental issues on globalization will first be analysed from a positive perspective (2); next, the influence of environmental issues on globalization will be analysed from a normative perspective (3). Then, the influence of globalization on (private) environmental law and policy will be analysed positively (4) as well as normatively (5). Finally, an indication will be provided of the particular contribution of environmental problems to the debate on the influence of globalization on private lawmaking (6).

9 See for the various possible remedies for transboundary environmental harm Nollkaemper (2008). 


\section{INFLUENCE OF ENVIRONMENTAL ISSUES ON GLOBALIZATION: POSITIVE ANALYSIS}

One can easily identify some environmental problems that have shaped, or at least influenced, the globalization debate. For now, I will simply mention a few of those issues and mainly be content with describing them; in the next section (3) an attempt will be made to address some of these developments from a more normative perspective.

\subsection{Increase of Transboundary Pollution}

It seems like pushing at an open door to argue that one way in which environmental problems have 'gone global' is that pollution problems have increasingly become transboundary. ${ }^{10}$ To a large extent, this may be the result of an increased awareness of the transboundary character of environmental pollution. ${ }^{11}$ Environmental pollution probably always had a transboundary character, but perhaps it is also due to increased technological abilities that the sources can be traced back to transboundary pollution. ${ }^{12}$ Originally, the focus of environmental awareness was on the so-called point source pollution coming from particular identifiable sources (such as emissions by factories), in addition to problems for workers ${ }^{13}$, leading to pollution of the soil and (local) surface or ground waters. Most likely, already during the time of industrialization, emissions by particular factories caused transboundary air pollution, but lacking technical abilities we were often prevented from tracking down the sources of air pollution. In the second half of the last century, the attention shifted as a result of an increasing awareness that many environmental problems have a transboundary character. Hence, the focus increasingly rested on problems caused by so-called long-range air pollution and acid rain. ${ }^{14}$

From an economic perspective, the basic problem was that local industry exported environmental pollution, leading, at least, to a de facto 'externalization' of pollution problems. Economists have often argued that the reasons for

\footnotetext{
10 See inter alia Lemke (2006).

11 See for a fuller account of the importance of transboundary impacts Handl (2007).

12 Also Bhagwati (2007) believes that globalization has been driven in an important way by technical change.

13 Notice that environmental law in many countries originated from a shift in attention from safety at work to the so-called external safety around the factory.

14 See for example the 1979 Geneva Convention on Long-Range Transboundary Air Pollution (LRTAP) and the subsequent protocols.
} 
the transboundary character of environmental pollution problems are well known: local politicians will not have many incentives to act strongly against polluters who may be able to export large quantities of the pollution outside the borders of the national territory. Thus the polluting activity could result in socio-economic benefits for the nation (increased tax revenues and job security), whereas the negative effects (referred to as externalities by economists) are shipped to the neighbouring countries. ${ }^{15}$ Since politicians primarily need to be re-elected by the citizens within their particular state, their primary concern may not be with the transboundary effects of pollution caused by factories within their nation. In that sense, one could even argue that one should not be surprised that such an externalization of pollution to other countries takes place. That problem is as such well known and not new. It has been, as mentioned in the introduction, the task of international environmental law to provide remedies against this externalization of pollution. These remedies, however, emerged long before globalization became an issue on the political or academic agenda.

There is, however, one particular issue that has definitely changed the political and academic agenda, namely what was referred to in the 1990s as global environmental change and in this century simply as the problem of climate change. If there is one example of a 'global' environmental problem it is undoubtedly climate change. Not only can sources not be traced back just to particular polluters in specific nation states, but so-called non point source pollution (such as aviation) has also largely contributed at least to increased $\mathrm{CO}_{2}$ emissions and arguably to climate change as well. The example of climate change immediately shows the difficulty in arguing that there would be a causal relationship between globalization and a particular environmental problem. One can undoubtedly argue that climate change is the ultimate example of a global environmental problem and in that sense it influences the globalization debate. On the other hand, it is obviously not necessarily (economic) globalization in the sense of lowering restrictions on trade that would have caused the climate change problem. For a more in-depth discussion of the legal aspects of climate change we refer to the relevant literature in that respect ${ }^{16}$ and more particularly to Chapter 13 by Spier in this volume.

\subsection{Increased Mobility of Products and Services}

Another clear example of a relationship between environmental issues and globalization (even though again the direction of the causality is not that clear)

15 See Faure and Betlem (2008, pp. 129-91).

16 Johnston (2008); Van Ierland et al. (2003), Stewart and Wiener (2003), Faure et al. (2003), Douma et al. (2007b) as well as Peeters and Deketelaere (2006). 
relates to the mere fact that as a result of technological changes, increased possibilities of transport, lower transportation costs and so on the mobility of products, capital, labour and services has strongly intensified. It is precisely this increased mobility which according to some qualifies as 'globalization'. The increased mobility and the corresponding increasing (international) trade have undoubtedly led to significant welfare gains which have been described in many economic studies. However, at the same time, many have also pointed to the fact that with an increased mobility of products and services not only do the beneficial aspects of these products increasingly travel but also the negative side-effects, earlier referred to as externalities. Indeed, one aspect is that the increased mobility not only applies to regular products but also for example to waste. The increasing technological possibilities provide inter alia for producers of waste possibilities to use economies of scale and enable them to look for the place where, for example, incineration costs (or taxes) may be the lowest. ${ }^{17}$ This export of environmental problems, leading effectively to a globalization of trade in pollution (more particularly waste), does not go undisputed.

Other examples of this relationship between increased mobility and environmental issues can be provided. Particular problems arise, for example, when products from a country with low environmental (or labour) standards are imported into countries with higher standards, whereby the question arises to what extent the higher environmental standards can also be imposed upon the imported products, which would effectively raise barriers to trade. ${ }^{18}$

In addition, in some cases, differences in the environmental standards (or in the pollution absorbing capacity) of countries have led to a mobility of firms. In that sense, the possibilities of increased mobility have effectively been used by many polluters who have, according to Tiebout's theory, 'voted with their feet' and moved particularly polluting activities to other jurisdictions. ${ }^{19}$ The increased exodus of, for example, textile firms from Europe towards Southeast Asia is one important example. ${ }^{20}$ Some argue that the enlargement towards Eastern Europe also provides increased possibilities for environmental mobility of firms in Western Europe to the east. ${ }^{21}$

\footnotetext{
17 See Lavrysen (1995).

18 See on this issue inter alia Vogel (2004).

19 See Tiebout (1956).

20 Although this obviously took place not only because of differences in environmental standards but also because of differences in labour costs, taxation, costs of raw material etc.

21 See Faure and Johnston (2009, forthcoming).
} 
The most literal form of an interrelationship between pollution and globalization could probably be found in systems where a trading in pollution rights is allowed. Whereas some economists still considered such a trading system as an original but rather crazy idea in the 1990s, after some experiments in the US, emissions trading has gained popularity at the policy level as the main instrument to fight climate change. Even though there is not yet a full globalization in the sense of an international emission trading scheme, there are important regional emission trading schemes, such as the one for greenhouse gases in the European Union. ${ }^{22}$

\subsection{Lowering Environmental Quality?}

The probably more interesting issue is whether the relationship between globalization and environmental pollution leads also to a lowering of environmental quality. ${ }^{23}$ The hypothesis would thus be that the increasing transboundary character of pollution would lead not only to an increased mobility of pollutants, but also to more pollution and hence to a lowering of environmental quality. This corresponds with an intuitive feeling, launched for example by the so-called anti-globalists, that free trade would be the enemy of environmental protection. ${ }^{24}$ The intuitive appeal of this argument rests on the economic notion referred to above that states will attempt to externalize environmental pollution. If this externalization took place without remedies, more trade would undoubtedly lead to more pollution. ${ }^{25}$ Another theoretical backing for this statement is that states would increasingly engage in a competition for ever lower environmental standards. Since states would desire to attract industry, they would lower their environmental standards and, since competing firms would do the same, a prisoner's dilemma would emerge, resulting in an overall lowering of environmental quality. It is the well-known problem of the race to the bottom. ${ }^{26}$

22 For an account of the first experiences, see Faure and Peeters (2008).

23 See for a strong statement that economic globalization negatively affects environmental quality: Mander (2003); for a more nuanced picture with a review of the empirical literature see Copeland and Taylor (2004, p. 7 ff.) (arguing inter alia that increased trade and economic growth also raises environmental quality).

24 Here again, one notices that it is difficult to distinguish between environmental problems affecting globalization versus globalization influencing environmental issues. The feeling is often that free trade agreements have a 'chilling effect' on domestic regulation to protect public health and the environment, so Wirth $(2007, \mathrm{p}$. 1).

25 For a critical perspective on this 'transboundary externality' argument in favour of centralization see Revesz (1996).

26 For a critical perspective on this race-to-the-bottom rationale for centralization see equally Revesz (1992). 
Notwithstanding the theoretical appeal, the empirical evidence for this race-to-the-bottom hypothesis is rather weak; at least it depends on the specific territory where one examines this phenomenon. David Vogel has for example powerfully argued that there is empirical evidence that states do not always engage in a race to the bottom, but in some cases in a so-called race to the top. ${ }^{27}$ The basic intuition is that export-oriented firms that have to comply with stringent (environmental) standards abroad will also strive for more stringent standards in their home country. Based on the experience in the state of California, this is referred to by some as the California effect. ${ }^{28}$ However, Princen shows that this California effect (competing for higher environmental standards) only works with strong public interest groups that collide with the interests of industry. The intuition here is that export-oriented firms may have an interest in imposing the stringent standards with which they have to comply in the export country also domestically, probably partly in an effort to raise barriers to entry. Their interests may hence coincide with those of green NGOs that are also (but obviously for different reasons) in favour of more stringent environmental standards in their home country and thus form a coalition with industry.

However, when those coalitions do not emerge (and hence no trading up takes place), there is also a risk that free trade may win from environmental protection. Empirical evidence depends very much upon the region one considers. For example, within the US and Europe, empirical evidence shows that industry does not relocate to 'pollution havens' simply because environmental costs in other (member) states would be lower. ${ }^{29}$ However, empirical research also indicates that environmental costs may be one of the elements taken into consideration by firms when deciding upon a new location. ${ }^{30}$ The relevant question is whether the benefits of moving (being the marginal costs related to the differential in costs of compliance with environmental standards) outweigh other costs (such as relocation costs). ${ }^{31}$ Another issue is of course to what extent environmental costs constitute an important element in total production costs. This may explain why, for example, for a firm in Germany it may be beneficial to move production to Indonesia (since marginal cost differences may be substantial) but not to Belgium (since marginal cost differences may be minimal).

27 It is what David Vogel refers to as the phenomenon of 'trading up': Vogel (1995).

28 See in this respect the interesting doctoral dissertation by Princen where he has analysed this phenomenon in detail: Princen (2002).

29 See Faure (1998, pp. 171-3).

30 See Jaffe et al. (1995).

31 See Kolstad and Xing (2002) as well as Becker and Henderson (2000) and Greenstone (2002). 
Whether increased 'globalization' (in the sense of mobility) of environmental pollution therefore leads to a lowering of environmental quality very much depends on the particular circumstances and the regions concerned. ${ }^{32}$ Roughly speaking, one could argue that within large federal systems like the EU and the US there is hardly a race to the bottom between (member) states (leading to a lowering of environmental quality) but that such a race to the bottom may be realistic in case of mobility from the developed north to the less developed south. ${ }^{33}$

\section{INFLUENCE OF ENVIRONMENTAL ISSUES ON GLOBALIZATION: NORMATIVE ANALYSIS}

Again, I should stress that one can debate whether the issues really concern the influence of environmental issues on globalization or whether it is rather the reverse. The division presented here is, as was mentioned, merely chosen for reasons of presentation, not so much for contents.

The normative questions that follow from the relationship between environmental issues and globalization which have been identified positively in Section 2 will now be addressed at a more normative level. Normatively, the question of course arises regarding to what extent one considers some of the phenomena resulting from an increased relationship between globalization and environmental pollution as desirable or not. Without attempting to provide a final answer to these complicated issues, I will only attempt to identify some ways in which one could address these problems. This may help in structuring the research and policy agenda. The increase in the transboundary character of environmental problems (and thus the globalization of environmental pollution) undoubtedly leads to questions related to, for example, the institutions that need to address these globalized environmental problems, the level of governance at which issues should be addressed and the consequences of the normative environmental standards to be imposed.

\subsection{Multi-Level Governance}

A first question at the normative level is, to put it simply, whether the globalization of environmental problems makes a globalization of law neces-

32 See Faure and Johnston (2009).

33 See in this respect Gupta (2006) who is for that reason very critical of applying the idea of regulatory competition also in the north-south relationship. For a detailed overview of the empirical literature in this respect see also Copeland and Taylor (2004). 
sary. ${ }^{34}$ The straightforward argument would be that a globalization of pollution necessitates a globalization of environmental law. ${ }^{35}$ Even though it sounds rather simplistic, the argument may have some support from economic analysis from two different angles. One angle would be that as soon as pollution crosses national borders and a risk of an externalization of environmental pollution thus emerges, a remedy should be found at a higher level to force the 'pollution exporting' state towards an internalization of its transboundary pollution. ${ }^{36}$ However, even though the argument that some legal remedy is necessary against this transboundary pollution is undoubtedly valid, the question remains as to whether this really should take the form of a centralization or harmonization of law.

An alternative presented in the literature is simply the transboundary application of domestic standards on transboundary pollution. ${ }^{36}$ There are many examples of this. In the European context one could notice an important evolution in the case law of the European Court of Justice allowing victims of transboundary environmental pollution to sue foreign polluters either in the state of the polluter or in the victim state. ${ }^{38}$ In the latter case (which is obviously more favourable for the victim) a foreign polluter would be confronted with an extra- territorial application of the victim state's law. For example in the Netherlands this has led to many cases brought by environmental NGOs and individual victims against Belgian and French polluters (of the rivers Rhine and Meuse) effectively claiming the application of Dutch law to pollution which had its source in Belgium and France respectively. ${ }^{39}$

However, while these types of remedies ${ }^{40}$ may work in particular contexts

34 Many of those issues are also addressed in the contributions in Winter (2006) and in Follesdal et al. (2008).

35 See Esty and Ivanova (2003).

36 See Van den Bergh (2000, pp. 88-92).

37 This could be done via a liability suit whereby a downstream victim of pollution sues upstream polluting firms. See on those possibilities Faure and Betlem (2008), Boyle (2006) and Nollkaemper (1998).

38 This was decided by the European Court of Justice in the well-known ruling in the Bier case (case 21/76 Bier v Mines de potasse d'Alsace, (1976) ECR 1735, 1748-9: 'The expression "place where the harmful event occurred"... must be understood as being intended to cover both the place where the damage occurred and the place of the event giving rise to it. The result is that the defendant may be sued, at the option of the plaintiff, either in the courts for the place where the damage occurred or in the court for the place of the event which gives rise to and is at the origin of the damage.'

39 See for a detailed discussion of these examples Faure and Betlem (2008, pp. 129-91).

40 Also advocated in many publications by Esty and Geradin. See inter alia Esty and Geradin (1997, 1998 and 2001). 
(like the Belgian-Dutch damage claims) the transboundary application of domestic standards can, as we will discuss below, to some extent also conflict with rules concerning free trade, emerging from either regional organizations (like the EU) or from world trade law. Hence, to some extent, the remedy against this transboundary pollution may have to come from a standard setting at a higher legal order. Institutionally, the transboundary character of the pollution would thus constitute an argument in favour of harmonization of environmental law, or at least in favour of a centralization of the decision making. ${ }^{41}$

A second related argument would be that when pollution crosses national borders, a decision-making authority has to be found that is large enough to deal adequately with the pollution problem. The justification in that particular case would simply be one of economies of scale: by looking for an authority which has jurisdiction over the entire territory covering the pollution problem, substantial savings on transaction costs could be achieved. This type of argument would hence justify, for example, shifting the standard setting for water pollution in transboundary rivers like the Meuse or Rhine to a body like the EU. It would equally justify shifting the decision making for a global environmental problem like climate change to an authority with global jurisdiction like the UN. ${ }^{42}$

\subsection{Shift of Governance for Local Pollution?}

The first normative issue I dealt with was the relatively straightforward case where the pollution crosses national borders. In that case, an argument in favour of shifting powers to a higher legal order (hence: globalization of pollution leading to globalization of law) is not that difficult to make. But what if the pollution is confined within national borders? There are still economic justifications for shifting powers to a higher legal order (centralization and eventually harmonization) even if the pollution problem remains local, but the case is weaker. I discuss this from two separate angles.

41 Centralization should indeed not necessarily mean harmonization. An obvious alternative is to shift powers (e.g. because of economies of scale advantages) to a higher level but to have the central authority impose differentiated standards. See in this respect inter alia Arcuri (2001, p. 37).

42 Hence, the fact that the UN dealt with the climate change problem in the wellknown Framework Convention on Climate Change has a strong economic justification in this economies of scale argument. 


\subsubsection{Danger of a race to the bottom?}

Above, I have already introduced the race to the bottom as one phenomenon that could explain a lowering of environmental quality resulting from an increased mobility of products, firms and pollutants. The resulting question is to what extent this race to the bottom may justify a centralization of the decision making, or at least a shift of the decision making to a higher legal order.

The literature in this respect usually indicates that this all depends on whether there is indeed empirical evidence of such a race to the bottom (which would then justify centralization). ${ }^{43}$ As I have already indicated above, ${ }^{44}$ the empirical evidence in that respect is not that clear. In cases where there would be evidence of a so-called California effect (precisely the reverse of the race to the bottom) there would not be any argument in favour of centralization. In the other case (competing for lower environmental standards), the question arises as to in which direction the empirical evidence goes. I have already indicated that within the EU and the US evidence of such a race to pollution havens is weak, even though after enlargement the EU may be confronted with an environmental race to Eastern Europe (all depending upon whether the Eastern European Member States have to comply with the acquis communautaire $^{45}$ and whether the European Commission will also actually enforce the stringent EU standards upon the new Member States).

The strongest empirical evidence rather comes from a race towards pollution havens in developing countries, which normatively therefore constitutes a pretty strong argument in favour of a regulation of environmental standards in developing countries. The difficulty in that particular case is, however, that a high level of environmental protection may not correspond to the preferences of citizens in low-income countries, who may prefer to give priority to economic development. ${ }^{46}$ Forcing developing low-income countries to comply with high levels of environmental protection may thus constitute a type of undesirable paternalism from the north.

Recent empirical evidence shows that the stringency of environmental regulation may at least have an influence on the ex ante decision of firms concerning location. Moreover, Esty and Gerardin have shown that, even in cases where there is no race to the bottom in the sense of a relocation to pollution

\footnotetext{
43 See in this respect also Chapter 3 by Van den Bergh in this volume.

44 See supra 2.3.

45 In most of the accession treaties, the new Member States were allowed large transition periods before they had to apply the environmental directives to the full extent. See for example treaty concerning the accession of the Republic of Bulgaria and Romania to the European Union, 21 June 2005, Official Journal L 157.

46 Schäfer (2006, p. 120) and compare Dunoff (2007, p. 88).
} 
havens, the fear of losing local industry to competing states with lower environmental standards could lead to a so-called 'regulatory chill', preventing the state from imposing more stringent environmental standards, because of the fear of a relocation. ${ }^{47}$

An argument which has sometimes been advanced in the EU in this respect is that environmental standards should be harmonized in order to create a level playing field for industry. The argument is sometimes referred to as the need for a 'harmonization of marketing conditions' ${ }^{48}$ Law and economics scholars have, however, powerfully shown that such a harmonization of marketing conditions cannot justify the need for harmonization of laws. The simple reason is that marketing conditions always differ (if not, there would be no trade) and, even if all legal rules were harmonized, marketing conditions would still be different because of totally other reasons (like differences in labour costs, tax level, unionization of the labour force, availability of natural resources and so on). ${ }^{49}$ The only relevant question is therefore whether these differences constitute a barrier to interstate trade, which is seldom the case..$^{50}$

\subsubsection{The trade-environment dispute}

In fact, the mirror image of the race to the bottom (whereby states would engage in an inefficient race towards lowering environmental standards) is the danger that some nations may impose very stringent domestic environmental standards. Since these will obviously also apply to imported products, they can endanger free trade. It is the well-known conflict between free trade and environmental concerns that has led to many regulations and publications both within federal systems (US, EU) and at the international level (WTO law). ${ }^{51}$ The bottom line is that most regulatory solutions start from a distrust of (member) states that use environmental reasons to, for example, prohibit the

$47 \quad$ See Esty and Geradin (2001).

48 In Europe an important goal of harmonization of laws has always been to remove differences in national environmental legislation, assuming that these would have a detrimental effect on the common market (see for example Jans and Vedder (2008, pp. 4-5)). See for example the observations preceding directive 76/464 of 4 May 1976 (OJ L 29): 'Whereas any disparity between the provisions on the discharge of certain dangerous substances into the aquatic environment already applicable or in preparation in the various Member States may create unequal conditions of competition and thus directly affect the functioning of the common market'.

49 See also Ogus (2004, pp. 177-9) and Revesz (1997).

50 See generally Esty (1999).

51 See Wirth (2007, p. 1). Under WTO law the issue is regulated by the agreement on the application of Sanitary and Phytosanitary Measures, known as the SPS Agreement. For a commentary see Scott (2007) and Van den Bossche and Prévost (2005). And see especially Prévost (2009). 
import of supposedly polluting products. ${ }^{52}$ The obvious danger that can always arise in those situations is that the environmental reasoning will be abused simply to favour local industry. Hence, many of the free trade agreements start from the negative position, namely that they prohibit local protectionism, even if it were for environmental reasons (although a genuine use of the environmental argument to ban polluting products may under some circumstances be accepted). ${ }^{53}$

Looking at the cases, legal doctrine has shown that the approaches seem to differ somewhat between the EU, the US and the WTO level. To start with the last: commentators have indicated that the tuna-dolphin case seems to indicate that the free trade interests have won. Indeed the US lost a challenge initiated by Mexico under the auspices of the predecessor of the WTO: ${ }^{54}$ the US ban on Mexican tuna (which was legitimately caught in a way that killed air-breathing dolphins) was considered an illegal discrimination against Mexican tuna. This US embargo amounted to an attempt of the US to dictate Mexico's environmental policy, which could have serious disruptive effects on international trade. ${ }^{55}$ The same seems to a large extent to be the case in US national law where the Supreme Court has decided that state laws may not create barriers to an interstate trade of waste. ${ }^{56}$

The EU approach, on the other hand, seems to be more flexible in the sense that it allows more room to call on environmental arguments to justify protective measures. ${ }^{57}$ For example, in the Danish bottle case a recycling system imposed by Denmark and clearly imposing costs on (also foreign) producers (thus potentially restricting trade) was allowed, given the environmental interests the Danish wished to achieve with the particular recycling system. ${ }^{58}$ Whereas the Danish bottle measure was still non-discriminatory, the Walloon

52 Hence international obligations in the area of trade law are often considered 'negative' in the sense that they place constraints on the possibilities of national governments to protect the environment or public health (Wirth 2007, p. 2).

53 For an interesting overview of the empirical and theoretical literature concerning the environmental consequences of economic growth and international trade see Copeland and Taylor (2004).

54 The General Agreement on Tariffs and Trade (GATT).

55 See Wirth (2007, pp. 2-3).

56 This has been based on the interpretation of the Commerce Clause, known as the Dormant Commerce Clause, whereby the Supreme Court reasoned that State and Local Laws had effectively created barriers to the interstate market in solid waste (see for example Fort Gratiot Sanitary Landfill, Inc. v Mich. Dep't of Natural Res., 504 U.S. 353 (1992); City of Philadelphia v New Jersey, 437 U.S. 617 (1978) and C\&A Carbone, Inc. v Town of Clarkstown, N.Y., 511 U.S. 383 (1994).

57 See generally on this case law van Calster (2002, pp. 482-5).

58 Case 302/86 Commission v Denmark, 1988 ECR 4607. See generally Temmink (2000). 
region in Belgium went a lot further by simply prohibiting the import of foreign waste into the Walloon region. Even though this measure was clearly discriminatory, the European Court of Justice (to the surprise of many commentators) upheld the measure. ${ }^{59}$ It called on the so-called proximity principle as a justification, arguing that the waste should in principle be treated or recycled as close as possible to the place where it has been produced. ${ }^{60}$ Hence the Walloon government was allowed to ban foreign waste even though the measure was clearly discriminatory.

Commentators hold that in principle multilateral environmental agreements should solve these problems. ${ }^{61}$ Moreover, others stress that one major problem in all of these trade-environment conflicts is scientific uncertainty. ${ }^{62}$ Often one country or legal system bans the import of particular products (such as GMOs or beef with hormones) because of particular food safety or environmental concerns, whereas the exporting country holds that these risks are either non-existent or largely exaggerated so that the importing state is again mainly abusing the environmental or health concern to ban imports, favouring local industry. That the latter concern may always play a role will be no surprise if one just remembers, for example, how quick the French were in banning British beef during the BSE crisis, obviously favouring local producers. ${ }^{63}$

Commentators indicate that the key to solving this conflict is to evaluate the validity of the local arguments (and especially the scientific uncertainty surrounding it) on the basis of expert science. However, since many of the recent conflicts have also shown that experts may strongly disagree as well, one key issue is to determine the procedure by which these kinds of decisions are taken (including, for example, whether one relies only on expert evidence or potentially also on public participation). ${ }^{64}$ Another issue is how, after risks have been appropriately assessed, whether one can find an agreement on the contents, notwithstanding different preferences and differences in risk aversion and perception.

59 Case C 2/90 Commission v Belgium, 1992 ECR I-4431.

60 This reasoning can of course be criticized from an economic perspective since it does not allow for making use of economies of scale in waste treatment and moreover may seriously limit competition. See for a critical analysis Von Wilmowsky (1993) and Doherty (2004).

61 Compare Brunnée (2006). See also Wirth (2007, pp. 4-5).

62 See Wiener (2004) and Zander (2009).

63 See on these issues in further detail Vos (2000).

64 There is overwhelming psychological evidence showing that unfortunately experts seem as prone to overconfidence as lay people, resulting in catastrophic misjudgements by experts as well (see Slovic et al. (2000, pp. 109-10)). 
Increasingly, commentators also ask the question whether, more specifically in issues relating to international trade, the WTO appellate body is the appropriate forum to answer many of these rather complicated technical issues.

\subsection{Mobility of Products, Firms and Services}

When dealing with the relationship between environmental problems and globalization there are of course also a number of normative issues involved, which to some extent go beyond the economic approach on which I have so far largely relied. One of the consequences of an increased mobility of polluters and pollutants may be that pollution is to a large extent exported to communities who do not reap the benefits from the social activities that cause the pollution. These kinds of issues are in the literature discussed under the heading of 'environmental justice'. ${ }^{65}$ Of course these complicated questions do not generate simple answers, but these environmental justice concerns will undoubtedly also (and rightly so) strongly determine the policy agenda concerning the relationship between environmental pollution and globalization. Just a few examples illustrate the relevance of these environmental justice issues.

One obvious question is to what extent competition and economies of scale can determine where to locate particular polluting industries. For example, in the north-south dialogue an economic approach may well propose the shipment of hazardous waste to the Sahara desert, where it could probably be stored at lower costs than the dismantling in, say, Europe would cost. ${ }^{66}$ However, such a race to the bottom to a pollution haven understandably raises important environmental justice concerns that may even trump the economic arguments. ${ }^{67}$

Similar questions also arise with respect to the application of environmental standards in developing countries. The question arises for example as to whether in the environmental protection-economic development trade-off policy makers should always respect the preferences of the citizens. This would lead to the conclusion that the inhabitants of, say, Togo would, given their higher preference for economic development than for environmental protection (and their lower income), probably not be prepared to pay the same high price for environmental protection as the citizens of, for example, Germany. A strict economic reasoning would thus lead to a differentiation of

\footnotetext{
65 See generally the contributions in Boyle and Anderson (1996) and Heringa (2006).

66 For a critical approach see Van Der Linde (2000).

67 See generally on this issue Porter (1999).
} 
environmental standards. ${ }^{68}$ However, justice notions may, for example, well lead companies that export their activities from Germany to Togo to adopt the same environmental standards in Togo as in Germany. Such a duty to export domestic high-level environmental standards to developing countries is sometimes defended under the heading of corporate social responsibility. ${ }^{69}$

However, one has to be very careful about accepting these justice arguments at face value, the problem being that they can lead to paternalism whereby developing countries are forced to accept a higher level of environmental protection on the basis of an interpretation of environmental justice in the north. The result may be that prices of products and services in developing countries in the south increase to an extent that does not correspond to their preferences. The crucial question is therefore who defines the precise contents of this environmental justice and whether these justice concerns can eventually set aside preferences of citizens.

\section{INFLUENCE OF GLOBALIZATION ON (PRIVATE) ENVIRONMENTAL LAW: POSITIVE ANALYSIS}

Again I should stress that the many aspects of the relationship between globalization and environmental pollution addressed in this chapter are strongly related. For reasons of presentation I will now focus on some consequences of globalization for (private) environmental law. With globalization in this particular context I refer both to economic globalization and to the fact that environmental problems have assumed a more global nature, as I discussed in Section 3. Given the focus of this book on the relationship between globalization and private law I will try to focus on some consequences for private environmental law, even though it may be clear that many of these consequences apply to other aspects of environmental law as well.

\subsection{Institutional}

One undeniable consequence of globalization for environmental law is that a shift has occurred towards more globalized lawmaking. Above I indicated that the transboundary character of the pollution problem merits the search for a level of governance by an institution with authority broad enough to cover the pollution problem to be regulated. That is effectively what to a large extent has

68 See Schäfer (2006) and Faure (2008).

69 See on this notion Chapter 9 by Sutherland in this volume as well as Nollkaemper (2006) and Ebbesson (2006). 
happened. In the area of environmental law one can undoubtedly notice a trend towards 'institutional globalization' in the sense of a shift of powers towards higher legal orders. For example, in regional organizations like the EU one can notice an increasing shift of competences, more particularly as far as environmental law is concerned, towards the regional level. A recent research calculated that in the Netherlands approximately 66 per cent of Dutch environmental law consists of EU environmental law. ${ }^{70}$ Hence, one simple consequence of the shift of powers to a higher legal order (resulting from the globalization of environmental problems) is that the national law of the nation state is increasingly affected and influenced by law which emerges from higher legal orders (in Europe, the EU).

Generally one can argue that the institutional globalization leads to a multilevel governance (lawmaking at different levels of government). In addition to environmental law generated by the nation state, one increasingly notices lawmaking by:

- international organizations, to deal with transboundary pollution problems, for example, the UN for climate change, the International Maritime Organization (IMO) for marine oil pollution and the Nuclear Energy Agency (NEA) of the OECD (Organisation for Economic Cooperation and Development) for nuclear liability

- regional organizations like the EU. ${ }^{71}$

A consequence of the shift of powers to these higher legal orders is that the norms generated at these higher levels subsequently have to be transposed or implemented (of course depending upon the national legal system) in national law, which raises particular problems such as lacking compliance (with international environmental agreements) ${ }^{72}$ or lacking implementation (in the case of EU law). ${ }^{73}$

\subsection{Procedural}

\subsubsection{Integration of various legal spheres}

The shift of powers to the higher legal orders mentioned above, as well as the multi-level governance of environmental problems (referring to the fact that norms are generated at the international, regional - for example, EU-and

\footnotetext{
70 Douma et al. (2007a).

71 See for a detailed account of the meanwhile very complicated and elaborated European environmental law inter alia Jans and Vedder (2008).

72 See on compliance problems Faure and Lefevere (2004).

73 See Macrory $(2005,2006)$ reprinted in Macrory (2008, pp. 713-34).
} 
national levels), leads to specific procedural issues and changes in the way traditional environmental law is applied. One can argue that this globalization has changed the way in which the judiciary deals with (private) environmental law. ${ }^{74}$ One consequence of the fact that standard-setting powers have often been shifted to higher levels (international or regional) is that the norms generated at these higher levels will also influence the adjudication in particular cases under national law. ${ }^{75}$ Since the national law that the judge is applying in the private legal relationships may often emerge from the international level, questions can arise with respect to the correct transposition or implementation of these norms in national law. ${ }^{76}$ The traditional tasks of the judges's judicial review have hence changed to include also the compatibility of national law with international (and European) legal rules. ${ }^{77}$

This raises important questions with respect to the application and validity of these international norms in private legal relationships. Of course the extent to which these international norms can and do play a role in private legal relationships may well strongly depend upon the nature of the international legal norm and the legal system in which they are applied. However, increasingly one can notice that (in various forms and to various extents) these international norms also affect the adjudication by national judges of private legal relationships. One example is the fact that environmental human rights play an increasingly important role in national environmental law as well. The European Court of Human Rights has repeatedly accepted that particularly serious cases of environmental pollution can constitute a violation of the right to life. ${ }^{78}$

\subsubsection{Effect of international law on private law}

Within this setting of a multi-level environmental governance, questions also arise not only as to whether national judges are bound by higher legal norms (within the framework of judicial review) but also as to the extent to which

74 See (more generally) Brown (2008) and Eckes (2008).

75 See on these changing tasks for the judiciary as a result of 'the globalization of law' also Cassese (2005).

76 See on the duty to transpose environmental directives in the EU into national law generally Jans and Vedder (2008, pp. 127-64).

77 See more generally on judicial review of administrative acts in the Member States of the European Union and the United States the contributions in Seerden (2007).

78 The European Court of Human Rights has broadened the application of art. 8 of the European Convention on Human Rights (protecting the right of private life and family life) such that it now encompasses claims that are essentially claims of environmental justice (see for example the case of Mrs. Lopez Ostra v Spain 9 December 1998). 
individuals (such as victims) can call on these higher legal norms or whether they can be held against particular individuals (polluters). The history of environmental human rights shows that these rights can provide individual victims of environmental pollution with a direct right of action, even if not granted in the national legal system.

The general rule in international law was that international legal rules only bind states and not individuals. Therefore the District Court of Bonn could decide that an individual victim (a farmer) of the Chernobyl incident could not sue the Soviet Union for a violation of international law. ${ }^{79}$ There have been situations, however, where norms of international law have played a role in transboundary liability suits. An example is a suit brought by Dutch market gardeners in the 1970s against the Mines de Potasse d'Alsace (MDPA) for discharging too much salt into the river Rhine, so that they could not make use of the water of the Rhine any more. In a remarkable judgment, the District Court of Rotterdam held that, since no rule of national law could be found to decide this case, it had to turn to unwritten international law and hence it applied the principle that no state can use its territory for activities that cause harm to another state. ${ }^{80}$ The District Court of Rotterdam thereby explicitly refers to the well-known Trail Smelter Case, which applied the so-called good neighbourliness principle. ${ }^{81}$ These cases show that the traditional boundaries between international and national environmental law become increasingly blurry, since in various ways the international level clearly influences adjudication at the national level as well. ${ }^{82}$

\subsubsection{Effect on public participation}

International environmental norms have also clearly affected the administration of environmental justice in national legal systems. One can easily name various international conventions related to access to justice that provide victims in national (member) states increasingly with rights to, for example, challenge administrative decisions that may negatively affect their interests. In this respect one should not merely point to conventions with respect to the

79 See for a discussion of this decision of the Civil Court of First Instance of Bonn of 29 September 1987 Rest (1997, pp. 116-22) and Nollkaemper (1998, pp. 3-4).

80 District Court of Rotterdam, Nederlandse Jurisprudentie 1979, 113, Netherlands Yearbook of International Law, 1980, volume 11, 326, and District Court of Rotterdam, 16 December 1983, Nederlandse Jurisprudentie 1984, 341, Netherlands Yearbook of International Law, 1984, volume 15, 471.

81 For a discussion of this Trail Smelter Arbitration see Bratspies and Miller (2006) and Sands (2003, pp. 241-2 and pp. 318-19).

82 See Boyle (2007). 
transboundary environmental impact assessment ${ }^{83}$ but also to the Aarhus Convention with respect to public participation. ${ }^{84}$

Interestingly, some commentators point to the fact that the implementation of some international norms and decisions (more particularly following from the WTO appellate body) may endanger national rights with respect to public participation. Whereas on the basis of national (in this case US) law victims would enjoy broad rights of public participation, the (international) obligation to comply with a decision of an international body can in some instances lead to the duty of the state to implement these decisions, thereby infringing upon rights of public participation which national law would normally grant the citizens. ${ }^{85}$

\subsubsection{Tendency toward consensual solutions?}

Another interesting issue of a procedural nature is that one can increasingly notice a tendency towards bargaining and alternative dispute resolution as a solution to environmental conflicts. For example, with respect to the rivers Rhine and Scheldt, international commissions have recently been given important tasks to improve the quality of the water in those transboundary rivers on the basis of a procedure of consultation and large stakeholder involvement. ${ }^{86}$ As far as the river Rhine is concerned, this consensual approach had a positive result in the sense that the target of getting the salmon back into the river Rhine was achieved. ${ }^{87}$

Also at the international level one can notice that transboundary environmental disputes are almost never solved by the judiciary. An environmental chamber of the International Court of Justice, instituted in 1993, was never used for that purpose and was therefore not reinstituted from $2006 .{ }^{88}$ The deci-

83 Such as the Convention on Environmental Impact Assessment in a Transboundary Context (1991), referred to as the Espoo Convention. For a discussion see Jacobs (2008).

84 The UNECE Aarhus Convention regulates access to environmental information, public participation in decision making in environmental matters and access to justice in environmental matters.

85 So Wirth (2007, pp. 5-6).

86 See for a description of these procedures Peeters (2008, pp. 192-224).

87 Internationale Kommission zum Schutz des Rheins (IKSR), Stromaufwärts. Bilanz Aktionsprogramm Rheins, Koblenz, 2003, 31 pp., http://www.iksr.org/fileadmin/user_upload/Dokumente/apr_iksr_dt_foto.pdf.

88 On the website of the ICJ (consulted on 11 December 2007) one can read 'With respect to the formation of a chamber pursuant to article 26, par. 1, of the statute, it should be noted that, in 1993, the court created a Chamber for Environmental Matters, which was periodically reconstituted until 2006. In the chambers thirteen years of existence, however, no state ever requested that a case be dealt with by it. The court consequently decided in 2006 not to hold elections for a bench for the said chamber.' 
sions taken by the International Court of Justice (ICJ) and the International Tribunal for the Law of the Sea (ITLOS) also show the reluctance of the judges to come to firm decisions providing a final solution to the entitlements of both parties. In many cases, the judges remarkably provide a few indications on how to resolve the dispute and then send the parties back to the negotiation table. ${ }^{89}$

Hence, the shift towards a higher legal order and the globalization of environmental problems has apparently also led to a different role of the judiciary in resolving (transboundary) environmental disputes: rather than providing firm and final entitlements (as is often the case in national environmental disputes) in the transboundary context, the judiciary seems more cautious and tends to stimulate bargaining between parties and consensual solutions..$^{90}$

\subsection{Contents}

The question one could of course ask is whether the globalization of lawmaking in the environmental area has also led to a convergence in the sense of a harmonization of environmental law. Centralization in the sense of shifting powers to a higher legal order should indeed not necessarily be equated with harmonization. Theoretically the central authority could also decide to issue differentiated environmental standards that take into account, for example, differing local environmental conditions. ${ }^{91}$

However, the shift to a higher legal order (resulting from the globalization of environmental pollution) has in almost all cases led to a harmonization of lawmaking as well. Centralization has therefore in this environmental area often in practice meant harmonization. Of course it may depend upon the particular area and the international legal norm concerned whether there still is room for differentiation. However, in most cases, whether the norm

89 See for example the so-called Southern Bluefin Tuna dispute which was dealt with by the International Tribunal for the Law of the Sea (ITLOS) which prescribed in a provisional measure inter alia 'Australia, Japan and New Zealand should resume negotiations without delay with a view to reaching agreements on measures for the conservation and management of Southern Bluefin Tuna' (for details see Romano, 2000, pp. 207-8).

90 Also in the Gabcikovo-Nagymaros dispute the International Court of Justice held that the parties should 'find an agreed solution that takes account of the objectives of the treaty, which must be pursued in a joint and integrated way, as well as the norms of international environmental law and the principles of the law of international water courses' (case concerning the Gabcikovo-Nagymaros project (1997) ICJ Reports 7, para. 140-41. For a discussion see Sands (2003, pp. 469-77) and Romano (2000, pp. 246-60).

91 See inter alia Arcuri (2001). 
emanates from an international organization (such as the UN, IMO, ${ }^{92} \mathrm{NEA}^{93}$ ) or from a regional one (EU) there may be some scope left for differentiation. ${ }^{94}$ However, especially at the EU level, one increasingly gets the impression that the scope for differentiation is relatively limited and that the policy objective is to strive for a convergence of norms. ${ }^{95}$

Even though convergence through harmonization of legal rules may often be the policy objective, that does of course not mean that that objective can always be realized. In many cases European directives, for example, will provide a framework that has to implemented in national Member States. Given the large differences in legal cultures of the Member States (and also in legal language), even one single text may lead to different interpretations and to differentiation between Member States. ${ }^{96}$

\section{INFLUENCE OF GLOBALIZATION ON (PRIVATE) ENVIRONMENTAL LAW: NORMATIVE ANALYSIS}

I will now address the same issues that were discussed from a positive perspective in Section 4 in a more normative analysis. Again, the aim is not to provide a final answer on how to solve the challenges identified in Section 4, but rather to provide a framework within which these questions could be addressed. To an important extent this will again rely on the economic analysis of law, although some other approaches may be used as well.

\subsection{Institutional}

\subsubsection{Lawmaking beyond the nation state}

In Section 4 we addressed a general feature of the relationship between

\footnotetext{
92 International Maritime Organization.

93 Nuclear Energy Agency (of the OECD).
}

94 For example the international conventions with respect to the civil liability for the operator of a nuclear power plant provide the broad scope of the financial compensation but leave some freedom to the states to determine (within particular limits) the precise amounts. For details see Faure and Van den Borre (2008, pp. 219-87).

95 However, also there one should be careful: in the first years European environmental policy was undoubtedly striving for a harmonization of national laws in order to avoid 'distortions of competition' (see Jans and Vedder, 2008, pp. 4-5). However, nowadays unilateral measures by Member States to protect their own environment remain, under strict conditions, still a possibility (see Van Calster, 2002, p. 484).

96 See for a particular strong argument that harmonization and convergence of legal rules within Europe would be impossible Legrand (2008, pp. 13-40). 
globalization and environmental law, namely that powers of lawmaking are increasingly shifted, in the words of Smits, 'beyond the nation state' ${ }^{97}$ One can notice shifts to international organizations (like the UN, IMO or NEA, but many others could be mentioned as well) or to regional organizations such as the EU. It is no surprise that the further away from the citizens concerned the decision making takes place, the greater the risk is that a countervailing power, taking into account the interests of the citizens, may be lacking. The literature in many domains, but also in the environmental area, has held that the shift of powers to higher legal orders (in other words centralization) may lead to a few of the questions central to this entire volume:

- Legitimacy: to what extent do international organizations have democratic legitimacy for their decisions $?^{98}$ That problem will more particularly emerge when environmental standards are set not by international organizations but by private (often industry related) organizations as well.

- Accountability: to what extent can politicians or bureaucrats that take decisions on environmental standards in international or regional organizations be held accountable for their decisions, for example by parliaments or other institutions representing the voice of the citizens? ${ }^{99}$

- Transparency: to what extent does decision making at the international or regional level take place in a transparent way, so that citizens can verify how a particular decision concerning an environmental standard was taken, which interests have played a role and why the decision was made to weigh the interests involved in a particular way, leading to the environmental standard concerned?

\subsubsection{Victim and environmental protection doubtful}

Many examples have been advanced in the literature showing that in the environmental area international organizations often take decisions where the legitimacy is doubtful, accountability is lacking and a transparency on how the decision was made is largely absent. Examples can be found in the area of the liability of the licensee of a nuclear power plant for a nuclear accident and the liability of the tanker owner for marine oil pollution. In both cases, international organizations (the IMO in the maritime area; the NEA and the

97 See Chapter 1 by Smits in this volume and see also Sand (2006). See also Hooghe and Marks (2003). See on this concept also Jansen and Michaels (2008).

98 See for an analysis of the legitimacy deficit in the EU as well as for methods to increase the democratic accountability in case of multi-level (environmental) regulation Follesdal (2008).

99 See generally on accountability (of legal institutions) Bovens (2007). 
International Atomic Energy Agency (IAEA) in the nuclear field) created international conventions in the 1960s which are largely beneficial for the particular industries: liability is strict, channelled to the operator or the tanker owner (thus excluding the liability of other parties potentially contributing to the risk). ${ }^{100}$ Most importantly: the liability is limited by imposing a financial cap on the damages due by the potential injurer. This deviates from the normal rules of tort law and can thus constitute an important benefit (in fact a subsidy) to the industry concerned. Legal commentators have therefore held that in both areas treaties were created that largely benefited the interests of industry and only to a very limited extent addressed environmental concerns or concerns of victims. $^{101}$

The reason for this imbalance has equally been indicated in the literature: in the lawmaking process within these international organizations there was (at least at the time when they were being created) a lack of a countervailing power representing the interests, for example, of victims or of the environment as such. Given the superior expertise of the regulated industries involved (the nuclear and the shipping industry respectively), it is clear that they could easily influence (via their national representatives, present at the negotiation table) the outcome of the treaties. It is striking in that respect that the outcome of the negotiations concerning the nuclear liability conventions is even more favourable for industry than the outcome in the civil liability convention with respect to marine oil pollution (regulating the liability of tanker owners). In the nuclear liability field, a countervailing power (for example, representing potential victims or non-nuclearized states) was absent, whereas in the maritime field the interests of the various states concerned do not all go in the same direction, since some states may be primarily maritime states (thus having a large interest in protecting the maritime industry) whereas others may be mostly the coastal states potentially affected by marine pollution. Moreover, in the maritime area not only the interest of the maritime industry is involved but also that of the oil industry, to which the maritime industry would like to shift part of the responsibility. ${ }^{102}$

It is also striking that, for example, where decisions concerning the liability in the same areas were not taken by international organizations but at a national level, the liability of the nuclear operator and the tanker owner respectively was surprisingly higher. A typical example in that respect is of course the case of the US. The US was always actively involved in negotiating the

100 See for the nuclear accidents Trebilcock and Winter (1997) and for marine oil pollution Boyd (2002, 2003), Wang (2007), Verheij (2007) and Hendrickx (2007).

101 See the sources quoted in the previous footnote.

102 See on this struggle between the different interests in the coming into being of the maritime liability conventions Wang (2007, pp. 197-241). 
international conventions, more particularly because this would serve its interests. ${ }^{103}$

Originally, this also provided a limitation on the liability of the operator of the nuclear power plant, but later the regime changed, as a result of which the Price-Anderson Act is much more favourable today than the international regime: substantially higher amounts for compensation are generated (roughly ten billion US dollars in the US regime versus one billion in the international regime) and public funding in the US regime is totally excluded. ${ }^{104}$ A similar story could be told as far as the liability for the oil pollution risk is concerned: instead of joining the international conventions, the US created the Oil Pollution Act which, again, is much more favourable (in the sense of no limits on the liability and higher amounts of compensation) than the international regime. ${ }^{105}$

\subsubsection{Green treaties or protectionism?}

These examples show (and many others could be provided) that shifting powers to higher legal orders may lead to problems of accountability and transparency, thus allowing a greater influence of industrial interests, leading to a lower quality environmental standard. However, in some cases the reverse may be true, in the sense that industrial lobbying may lead to the imposition of inefficiently stringent environmental standards. That is the case more particularly when standards are used to create barriers to entry, thus limiting competition on the market. Typical examples of this protectionism can be found in the EU, where industry within 'green' Member States may typically lobby in favour of the imposition of stringent (but sometimes inefficient) standards at the EU level. The reason is that they already have to comply with stringent domestic environmental standards and may thus have an interest in imposing those at the EU-wide level as well. It may give the opportunity to erect barriers to entry, for example to southern competitors who are probably not able (and may not need) these stringent environmental standards. ${ }^{106}$

Similar problems may also arise at the national level. In most legal systems the executive has the treaty-making power. A shift to a higher level of governance (more particularly to international organizations) can thus at the national level lead to a more limited role of parliaments. In some cases they merely have the power to confirm or reject the treaty negotiated by the executive but not to

103 The US strongly lobbied in favour of the Paris Convention; at the same time the US created for the nuclear risk in 1957 the Price-Anderson Act (see for details Van den Borre (2007)).

104 See Faure and Van den Borre (2008, pp. 219-87).

105 Wang (2007, pp. 197-241).

106 See Faure (1998, pp. 169-75). 
influence its contents. ${ }^{107}$ This general problem of the lack of democratic legitimacy of international lawmaking has of course often been mentioned and, as was just shown, plays a role in environmental cases as well. ${ }^{108}$

\subsubsection{Limited public participation}

The current shift of powers to the higher legal order may lead to limited public participation for the citizens concerned in various ways. First, international organizations may not have involvement of the civil society (like environmental NGOs) in the decision-making process to the same extent as would be the case at the national level. In this respect the situation has of course largely changed compared with the 1960s, when the conventions concerning nuclear liability and marine oil pollution (referred to above) were drafted. Many international organizations now allow for a large stakeholder involvement in the decision-making process, ${ }^{109}$ but important differences still exist between the various international regimes concerned. Second, the influence of civil society is as such, as a result of the shift to a higher legal order, also limited for the simple reason that there is less to decide at the local level. One notices that, for example, when within national Member States decisions have to be taken on environmental standards, the debate often ends with the statement by the executive that these are international obligations that have to be implemented at the national (local) level. This limits the room for democratic control by parliament, but also for public participation or NGO involvement when setting these standards at the local level.

To an important extent, the shift of powers to the higher legal order (even though necessary as far as transboundary pollution is concerned) may thus not be totally unproblematic. To the extent that there is a lack of transparency and accountability, industrial interest groups may have more possibilities for successful lobbying and it is easier (given the lack of transparency) for politicians to provide what the interest groups demand. This may inevitably have a negative consequence for the quality of environmental standards.

107 See on these challenges to accountability and democracy resulting from multi-level regulation Wessel and Wouters (2008).

108 Also in US legal doctrine the dominant position of the president in negotiating international treaties and the subordinate function of Congress has been criticized (see Wirth, 2004, p. 399).

109 This increasing attention to stakeholder involvement and to the role of NGOs corresponds with a shift in the way (environmental) treaties are viewed, which is characterized as a shift from the sovereignty approach towards a managerial approach. See in this respect Chayes and Chayes (1995). This is a shift that one can also increasingly notice in international environmental agreements. See Faure and Lefevere (2004, pp. 163-80). 


\subsubsection{Shift problematic}

It seems as if this creates a dilemma: the normative answer to these problems is obviously not to shift back powers to local institutions. Indeed, above I have indicated that to the extent that environmental problems cross national borders it makes absolute sense to shift powers to a higher legal order. ${ }^{110}$ The wellknown saying 'global problems need global solutions' makes some sense in this respect. However, it was equally indicated that for a variety of reasons (mostly because it serves the interests of the industry involved and perhaps some bureaucrats in regional or international organizations as well) more powers are shifted to the international level than would be warranted on economic grounds. This is more particularly the case when powers are shifted to a higher level for pollution problems whose consequences are confined within the borders of the Member States.

The race to the bottom and the 'harmonization of marketing conditions' are then advanced as reasons for shifting powers to higher legal orders, but I indicated that these reasons are both theoretically and empirically very weak. ${ }^{111}$ That may be a reason to be slightly more careful with shifting lawmaking powers to higher levels when transboundary pollution is not at stake. Given the danger of a lack of transparency and a strong influence of industrial interest groups at the international level, it may constitute yet another argument in favour of decentralization where centralization is not absolutely necessary on economic grounds. ${ }^{112}$ But even in cases where the transboundary character of the pollution problems merits a shift to a higher legal order, problems may still arise, especially when the civil society has not been involved in the decision making. This is more particularly a problem since, while decision making can take place at a higher legal order, implementation has ultimately to take place at the local level (following yet another popular one-liner 'think globally, act locally').

\subsubsection{Possible remedies}

There may be obvious remedies to these problems (although not simple to implement in practice):

- One remedy would consist of seriously rethinking the shift of powers to higher legal orders and limiting this to the cases where centralization is needed on economic grounds (more particularly when there is a transboundary externality or empirical proof of a race to the bottom).

\footnotetext{
$110 \quad$ See supra Section 3.1.

111 See supra 3.2.

112 A similar argument is also made by Van den Bergh in Chapter 3 of this volume.
} 
- Second, one could work towards increased transparency at the international level as well. ${ }^{113}$ This would in public choice terms increase the costs of lobbying by interest groups. If the public at large can (as a result of increased transparency) notice that politicians are in fact favouring interest groups, lobbying becomes more difficult and there is a greater likelihood that environmental standards are set in the public interest.

- Third, it is obvious that the involvement of the civil society and public participation in general (also at the international level) can increase the quality of the decision making. By allowing in environmental NGOs with strong commitment and expertise in the environmental field, a serious counterweight against lobbying by industry can be provided.

These normative solutions are obviously not new. One can now increasingly notice that in more recent environmental treaty regimes there is indeed more transparency and a greater stakeholder involvement. It is the first remedy, implying that when pollution problems do not cross national borders there may be strong arguments in favour of decentralization rather than centralization, that seems to be the most difficult one to be implemented in practice. This may, to some extent, be due to the fact that bureaucrats in international organizations (and regional ones like the EU) of course also have a strong interest in continuing the shift of powers to higher legal orders since it confirms their authority and power. To a large extent the fact that more centralization takes place than is strictly needed (for example, in Europe) can be explained by the strong powers of the bureaucracy involved.

\subsection{Procedural}

\subsubsection{Distinction international-national becomes blurry}

Above, we have already indicated that one consequence of the 'globalization of law' is that norms set by regional or international organizations increasingly play a role in private legal disputes in national states as well. Moreover, the national judge will often be called to examine whether national law corresponds with these supranational norms. ${ }^{114}$ Hence, also the contents of judicial review have changed.

There seems to be an interesting shift of paradigm in the relationship between national and international law in the sense that the old dogma that international law is only binding upon the national states (in a broad sense) is changing as well. Above we referred to the decision of the District Court of

\footnotetext{
113 See Prechal and de Leeuw (2007, 2008).

114 See on these issues also Whytock (2007) who refers to the governance of transnational activity by domestic courts as 'transnational judicial governance'.
} 
Bonn, refusing to apply international law in a dispute between a German farmer and the Soviet Union. However, the District Court of Rotterdam had no difficulty in calling on international law in a private legal dispute between market gardeners in the Netherlands and the Alsacian salt mines in France. Perhaps this constitutes a paradigm shift whereby the worlds of national and international law are no longer so strongly separated. ${ }^{115}$ The result would be that international law would not only play a role after appropriate transposition in member states, but that under certain circumstances citizens may also directly call on (self-execution) provisions in international legal treaties. ${ }^{116}$

\subsubsection{Successful bargaining?}

An interesting tendency described above is that international disputes are increasingly settled through bargaining and negotiations rather than by allocating firm and definite entitlements. There may be a strong economic logic for this: the judiciary may well lack the necessary information to determine entitlements in a final way. Moreover, there is a likelihood that when entitlements are wrongly allocated, negotiations will (as a result of strategic behaviour by states) not be possible and inefficiencies may emerge.

Several examples were provided above showing that consensual solutions are increasingly used to solve international disputes. Also the judiciary seems in many cases to send the parties back to the negotiation table, merely providing them with some indications on how to solve the dispute. That may thus be a strategy to facilitate efficient bargaining. ${ }^{117}$

At first blush, there seems to be some empirical evidence that these consensual solutions are, at least as far as the resolution of transboundary environmental pollution is concerned, effective. ${ }^{118}$ Interestingly, there is some empirical evidence that the consensual solution chosen in the river Rhine case (through the Rhine Commission) generated better ecological results than a regulatory (command and control) approach followed in the Great Lakes case in the US. ${ }^{119}$

However, one still has to be careful: the mere fact that there now are a few examples where the consensual solution may have worked should not immediately lead to a generalization of conclusions. One problem that still remains

\footnotetext{
115 That is a claim inter alia made by Nollkaemper (2008).

116 For a more detailed account of these developments see Boyle (2006, p. 559) and Nollkaemper (1998, pp. 3-11).

117 Leading to efficient solutions as proposed by Coase (1960, pp. 1-44). See also Ayres and Talley (1995), Farrell (1987) and Johnston (1995).

118 See Peeters (2008, pp. 192-224).

119 Verwey (2000, pp. 1007-54).
} 
is that these 'softer' consensual solutions may lack enforcement teeth in case of non-compliance. ${ }^{120}$

\subsection{Contents: Differentiation of Standards}

The policy logic so far has always been that, since transboundary environmental problems require transboundary solutions, a centralization of decision making is needed. Moreover, the centralization has in practice almost always automatically been equated with a harmonization of environmental standards. This leads to the normative question regarding to what extent a total convergence of environmental standards is indeed desirable. There is an important strand of law and economics literature ${ }^{121}$ holding that (in the absence of transboundary externalities and empirical evidence of a race to the bottom) there should still be room for divergence. The arguments in favour of divergence, in the environmental field implying a differentiation of environmental standards, can be based on a variety of grounds. First of all, with respect to environmental problems, location specific circumstances are always different. Hence, there can be a strong technical reason to adapt standards to varying location specific circumstances. Second, the legal cultures are also strongly divergent. Many have, moreover, indicated that even if one were to harmonize law formally this would not necessarily lead to a convergence in practice. The reason is that even a similar wording (for example, imposed by a European directive) may be differently interpreted in different (member) states, taking into account their own legal culture. ${ }^{122}$

Moreover, harmonization of law in practice often means that particular standards representing the legal cultural values of a majority (or of the strongest players) will be imposed. In practice, this may mean that more particularly in a globalizing world harmonization would not respect differing values in the multicultural society.

On the contrary, many legal and economic scholars have pointed to the advantages of differentiation. This could lead to competition between legal orders. This competition can have the advantage that learning processes occur whereby legislators can benefit from various experiences in different legal systems. ${ }^{123}$ That benefit would be lost if the monopoly of one harmonized

120 See on potential problems with negotiated (environmental) agreements generally Johnston (2000) and Grimeaud (2004).

121 Well represented and summarized in this volume in Chapter 3 by Roger van den Bergh.

122 See in this respect also Van Dam (2007, pp. 53-76).

123 This point is strongly made in many publications by Van den Bergh. See inter alia Van den Bergh (2000) and Chapter 3 by Van den Bergh in this volume. 
legal system were imposed. A similar argument in favour of divergence has been strongly presented by Smits in many publications. He argues in favour of diversity, especially in the area of private law, maintaining that parties should (more particularly in contract law) have the possibility to choose from a variety of legal solutions. ${ }^{124}$

The conclusion is therefore straightforward: from this economic but also legal perspective globalization of law should not necessarily lead to a globalization of (environmental) standards but could lead to a differentiation, taking into account differing preferences, cultures and location specific circumstances.

\section{CONTRIBUTION OF ENVIRONMENTAL LAW TO THE GLOBALIZATION DEBATE}

\subsection{Environmental Issues that Shape the Globalization Debate}

As a summary, and by way of conclusion, an attempt can be made to indicate how environmental problems contribute to the debate on the influence of globalization on private law.

One can certainly argue that environmental problems have played an important role in that debate, since many of the legal issues related to globalization more particularly play a role with regard to environmental problems. One example is the issue of multi-level governance, that is, the question of at what level of governance decisions should be taken and how these various levels mutually interact. Given the inherent transboundary character of environmental problems, environmental issues have certainly influenced the debate on the optimal level of decision making.

Another area where environmental issues have shaped the debate is the well-known question (that has led to an abundant literature) of how free trade can be reconciled with environmental concerns.

\subsection{Influence of Globalization of Environmental Private Law}

It is also not difficult to state that globalization has had a clear influence on private legal relationships, including in the environmental area. One can for example point to international conventions (like Aarhus) that promote environmental rights, access to justice and information, and public participation. These are undoubtedly examples of international conventions that have had a

\footnotetext{
124 Smits (1998, p. 328).
} 
positive influence on public participation. To the extent that these international conventions are regarded as an element of globalization, this could be judged a positive result.

On the other hand, I have equally indicated that many developments resulting from this globalization (more particularly the shift to higher legal orders) undoubtedly also have a negative effect as far as the involvement of civil society is concerned, since decision making takes place further away from the citizens concerned. The role of national parliaments or local authorities is then often reduced to implementing international obligations. Here, one can undoubtedly argue that the increasing shift to higher legal orders (resulting from globalization) has led to problems of accountability, transparency and democratic legitimacy of (environmental) decision making.

Another aspect that environmentalists would undoubtedly consider a negative consequence of globalization is that local (state) laws protecting the environment can in some cases be set aside for violating rules of free trade. It is a well-known criticism of WTO law by anti-globalists. Also, the interpretation of the US Commerce Clause by the Supreme Court shows that trade concerns often win over environmental concerns. Only the case law of the European Court of Justice seems to give more room to environmental concerns, even when this limits free trade in a discriminatory way. However, this case law certainly does not go undisputed.

\subsection{Many Unresolved Issues...}

A brief look at the way in which globalization and environmental legal issues interrelate shows that there are many unresolved issues that need further attention. In that sense the environmental issues can help to shape the research agenda. To mention just a few:

- There is undoubtedly a need to increase the transparency of decision making and the accountability of international institutions responsible for drafting international environmental standards. Important steps have already been taken in this respect (more particularly in the climate change regime), but a lot still remains to be improved.

- More generally, the accountability and democratic legitimacy of foreign policy affecting environmental issues needs to be increased. The involvement of stakeholders and parliament at an early stage of the decision making needs to be improved.

- The level of the decision making in a multi-level governance setting needs to be rethought: there seems to be too large a shift of powers to the regional/international level, including in cases where this may not be strictly needed. Possibilities of combining centralization (where this is 
needed) on the one hand with the setting of differentiated norms on the other hand also need to be further explored.

- In order to increase the respect for the rule of law and the accountability of decision-makers at the international level, access to justice, public participation and the involvement of civil society could be further improved.

- The framework for striking the balance between free trade and environmental concerns also merits further research. This is particularly the case when there is scientific uncertainty, which raises the question of who shall take decisions on the extent to which environmental concerns can trump free trade. The question also arises regarding to what extent these decisions can/should only be based on scientific evidence and to what extent public participation is needed as well.

\section{4 ... Need Multidisciplinary Research!}

It may be clear that answering some of these questions goes beyond the scope of legal research and may need the involvement of other disciplines. For example:

- Economists may be needed to assist in determining how to set efficient standards and to determine what is (within a multi-level governance setting) an optimal level of decision making.

- Social scientists are needed to assist in explaining how an involvement of civil society, public participation and better access to justice can be guaranteed, but also how standards can be set in a multicultural setting, respecting differences in preferences and (legal) cultures.

- Political scientists have important insights into how to provide a countervailing power to industrial lobbying, how the transparency of the decision-making processes at the international level can be increased, and in general how decision making concerning environmental standards can be done in the public interest.

In sum, in order to answer some of the challenges posed by the relationship between globalization and environmental problems, undoubtedly a multidisciplinary approach is needed.

\section{REFERENCES}

Arcuri, A. (2001), 'Controlling Environmental Risk in Europe: The Complementary Role of an EC Environmental Liability Regime', Tijdschrift voor Milieuaansprakelijkheid (Environmental Liability Review), pp. 37 and following. 
Ayres, I. and E. Talley (1995), 'Solomonic Bargaining: Dividing a Legal Entitlement to Facilitate Coasean Trade', Yale Law Journal, 104, pp. 1027 and following.

Baker, S. and J., McCormick (2004), 'Sustainable Development: Comparative Understandings and Responses', in N.J. Vig and M.G. Faure (eds), Green Giants? Environmental Policies of the United States and the European Union, Cambridge: MIT Press, pp. 277-302.

Becker, R.A. and J.V. Henderson (2000), 'Effects of Air Quality Regulations on Polluting Industries', Journal of Political Economy, 108, pp. 379-421.

Bhagwati, J. (ed.) (2007), In Defense of Globalization, New York: Oxford University Press.

Birnie, P.W. and A. Boyle (eds) (2002), International Law and the Environment, 2nd edition, Oxford: Oxford University Press.

Bovens, M. (2007), 'Analysing and Assessing Accountability: A Conceptual Framework', European Law Journal, 13 (4), pp. 447-68.

Boyd, J. (2002), 'Financial Responsibility for Environmental Obligations: Are Bonding and Assurance Rules fulfilling their Promise?', in T. Swanson (ed.), An Introduction to the Law and Economics of Environmental Policy: Issues in Institutional Design, Amsterdam: JAI Press, pp. 417-85.

Boyd, J. (2003), 'A Market-Based Analysis of Financial Insurance Issues associated with US Natural Resource Damage Liability', in M. Faure (ed.), Deterrence, Insurability, and Compensation in Environmental Liability: Future Developments in a European Union, Vienna: Springer, pp. 258-302.

Boyle, A.E. (2006), 'Globalizing Environmental Liability: The Interplay of National and International Law', in G. Winter (ed.), Multi-level Governance of Global Environmental Change: Perspectives from Science, Sociology and the Law, Cambridge: Cambridge University Press, pp. 559-86.

Boyle, A. (2007), 'Relationship between International Environmental Law and Other Branches of International Law', in D. Bodansky, J. Brunnée and E. Hey (eds), The Oxford Handbook of International Environmental Law, Oxford: Oxford University Press, pp. 125-46.

Boyle, A. and M. Anderson (eds) (1996), Human Rights Approaches to Environmental Protection, Oxford: Clarendon Press.

Bratspies, R.M. and R.A. Miller (eds) (2006), Transboundary Harm in International Law: Lessons from the Trail Smelter Arbitration, Cambridge: Cambridge University Press.

Brown, R.S. (2008), 'How Do Judges Cope with Multi-level Regulation?', in A. Follesdal, R.A. Wessel and J. Wouters (eds), Multi-level Regulation and the EU: The Interplay between Global, European and National Normative Processes, Leiden: Martinus Nijhoff, pp. 213-30.

Brunnée, J. (2006), 'Multilateral Environmental Agreements and the Compliance Continuum', in G. Winter (ed.), Multi-level Governance of Global Environmental Change: Perspectives from Science, Sociology and the Law, Cambridge: Cambridge University Press, pp. 387-408.

Bugge, H.C. and C. Voigt (eds) (2008), Sustainable Development in International and National Law, Groningen: Europa Law Publishing.

Cassese, S. (2005), 'The Globalization of Law', New York University Journal of International Law and Politics, 37, pp. 973-93.

Chayes, A. and A.H. Chayes (eds) (1995), The New Sovereignty: Compliance with International Regulatory Agreements, Cambridge: Harvard University Press.

Coase, R. (1960), 'The Problem of Social Cost', Journal of Law and Economics, pp. $1-44$. 
Copeland, B.R. and M.S. Taylor (2004), 'Trade, Growth, and the Environment', Journal of Economic Literature, 42, pp. 7-71.

De Prado, C. (ed.) (2007), Global Multi-level Governance: European and East Asian Leadership, Tokyo: United Nations University Press.

Doherty, M. (2004), 'Hard Cases and Environmental Principles: an Aid to Interpretation?', in H. Somsen et al. (eds), The Yearbook of European Environmental Law, 3, Oxford: Oxford University Press, pp. 57 and following.

Douma, W.T. et al. (2007a), 'Europese Invloed op Regelgeving Meetbaar' (European Influence on Legislation Can be Measured), Nederlands Juristenblad, pp. 1828-34.

Douma, W.T., L. Massai and M. Montini (eds) (2007b), The Kyoto Protocol and Beyond: Legal and Policy Challenges of Climate Change, The Hague: T.M.C. Asser Press.

Dunoff, J.L. (2007), 'Levels of Environmental Governance', in D. Bodansky, J. Brunnée and E. Hey (eds), The Oxford Handbook of International Environmental Law, Oxford: Oxford University Press, pp. 85-106.

Ebbesson, J. (2006), 'Transboundary Corporate Responsibility in Environmental Matters: Fragments and Foundations for a Future Framework', in G. Winter (ed.), Multi-level Governance of Global Environmental Change: Perspectives from Science, Sociology and the Law, Cambridge: Cambridge University Press, pp. 200-224.

Eckes, C.H.R. (2008), 'Trapped between Courts or How Terrorist Suspects Lost Their Right to a Remedy', in A. Follesdal, R.A. Wessel and J. Wouters (eds), Multi-level Regulation and the EU: The Interplay between Global, European and National Normative Processes, Leiden: Martinus Nijhoff, pp. 261-99.

Esty, D.C. (1999), 'Economic Integration and the Environment', in N.J. Vig and R.S. Axelrod (eds), The Global Environment: Institutions, Law, and Policy, Washington: CQ Press, pp. 190 and following.

Esty, D.C. and D. Geradin (1997), 'Market Access, Competitiveness, and Harmonization: Environmental Protection in Regional Trade Agreements', Harvard Environmental Law Review, 21, pp. 265 and following.

Esty, D.C. and D. Geradin (1998), 'Environmental Protection and International Competitiveness: A Conceptual Framework', Journal of World Trade Law, 32, pp. 5 and following.

Esty, D.C. and D. Geradin (2001), 'Regulatory Co-opetition', in D.C. Esty and D. Geradin (eds), Regulatory Competition and Economic Integration: Comparative Perspectives, Oxford: Oxford University Press, pp. 30-47.

Esty, D.C. and M.H. Ivanova (2003), 'Toward a Global Environmental Mechanism', in J.G. Speth (ed.), Worlds Apart: Globalization and the Environment, Washington: Island Press, pp. 67-82.

Farrell, J. (1987), 'Information and the Coase Theorem', Journal of Economic Perspectives, pp. 113 and following.

Faure, M. (1998), 'Harmonization of Environmental Law and Market Integration: Harmonizing for the Wrong Reasons?', European Environmental Law Review, pp. 169-75.

Faure, M.G. (2008), 'Environmental Rules versus Standards for Developing Countries: Learning from Schäfer', in T. Eger, J. Bigus, C. Ott and G. von Wangenheim (eds), Internationalisierung des Rechts und seine ökonomische Analyse Internationalization of the Law and its Economic Analysis: Festschrift für HansBernd Schäfer zum 65. Geburtstag, Wiesbaden: Gabler, pp. 735-46.

Faure, M. and G. Betlem (2008), 'Applying National Liability Law to Transboundary 
Pollution: Some Lessons from Europe and the United States', in M. Faure and Y. Song (eds), China and International Environmental Liability: Legal Remedies for Transboundary Pollution, Cheltenham, UK and Northampton, MA, USA: Edward Elgar, pp. 129-91.

Faure, M.G. and J.S. Johnston (2009), 'The Law and Economics of Environmental Federalism: Europe and the United States Compared', Virginia Environmental Law Journal, 27, pp. 205 and following.

Faure, M.G. and J.G.J. Lefevere (2004), 'Compliance with Global Environmental Policy', in R.S. Axelrod, J.D.L. Down and N.J. Vig (eds), The Global Environment: Institutions, Law and Policy, 2nd edition, Washington: CQ Press, pp. 163-80.

Faure, M. and M. Peeters (eds) (2008), Climate Change and European Emissions Trading: Lessons for Theory and Practice, Cheltenham, UK and Northampton, MA, USA, Edward Elgar.

Faure, M. and G. Skogh (eds) (2003), The Economic Analysis of Environmental Policy and Law: An Introduction, Cheltenham, UK and Northampton, MA, USA: Edward Elgar.

Faure, M. and Y. Song (eds) (2008), China and International Environmental Liability. Legal Remedies for Transboundary Pollution, Cheltenham, UK and Northampton, MA, USA: Edward Elgar.

Faure, M.G. and T. Van den Borre (2008), 'Compensating Nuclear Damage: A Comparative Economic Analysis of the US and International Liability Schemes', William \& Mary Environmental Law and Policy Review, 33, pp. 219-87.

Faure, M., J. Gupta and A. Nentjes (eds) (2003), Climate Change and the Kyoto Protocol: The Role of Institutions and Instruments to Control Global Change, Cheltenham, UK and Northampton, MA, USA: Edward Elgar.

Follesdal, A. (2008), 'Epilogue: Toward More Legitimate Multi-level Regulation', in A. Follesdal, R.A. Wessel and J. Wouters (eds), Multi-level Regulation and the EU: The Interplay between Global, European and National Normative Processes, Leiden: Martinus Nijhoff, pp. 377-98.

Follesdal, A., R.A. Wessel and J. Wouters (eds) (2008), Multi-level Regulation and the EU: The Interplay between Global, European and National Normative Processes, Leiden: Martinus Nijhoff.

Greenstone, M. (2002), 'The Impacts of Environmental Regulations on Industrial Activity: Evidence from the 1970 and 1977 Clean Air Act Amendments and the Census of Manufactures', Journal of Political Economy, 110, pp. 1175 and following.

Grimeaud, D.J.E. (2004), "Convergence or Divergence in the Use of "Negotiated Environmental Agreements" in European and US Environmental Policy: An Overview', in N.J. Vig and M.G. Faure (eds), Green Giants? Environmental Policies of the United States and the European Union, Cambridge: MIT Press, pp. 159-81.

Gupta, J. (2006), 'Regulatory Competition and Developing Countries and the Challenge for Compliance Push and Pull Measures', in G. Winter (ed.), Multi-level Governance of Global Environmental Change: Perspectives from Science, Sociology and the Law, Cambridge: Cambridge University Press, pp. 455-69.

Handl, J. (2007), 'Transboundary Impacts', in D. Bodansky, J. Brunnée and E. Hey (eds), The Oxford Handbook of International Environmental Law, Oxford: Oxford University Press, pp. 531-49.

Hendrickx, R. (2007), 'Maritime Oil Pollution: an Empirical Analysis', in M. Faure and A. Verheij (eds), Shifts in Compensation for Environmental Damage, Vienna: Ectil, pp. 243-60. 
Heringa, A.W. (2006), 'Human Rights and General Principles and Their Importance as a Legislative Technique: Do They Matter in Legislation? An Analysis with Specific Reference to Environmental Protection', in M. Faure and N. Niessen (eds), Environmental Law in Development: Lessons from the Indonesian Experience, Cheltenham, UK and Northampton, MA, USA: Edward Elgar, pp. 9-23.

Hooghe, L. and G. Marks (2003), 'Unravelling the Central State but How? Types of Multi-level Governance', American Political Science Review, 97 (2), pp. $233-43$.

Howse, R. (2008), 'The End of the Globalization Debate: A Review Essay', Harvard Law Review, 121, pp. 1528-54.

Jacobs, J. (2008), 'A New Look at Environmental Impact Assessments: Using Customary Law to Prevent Domestic and Transboundary Environmental Damage', in M. Faure and Y. Song (eds), China and International Environmental Liability: Legal Remedies for Transboundary Pollution, Cheltenham, UK and Northampton, MA, USA: Edward Elgar, pp. 225-52.

Jaffe, A.B., S. Peterson, P. Portney and R. Stavins (1995), 'Environmental Regulation and the Competitiveness of U.S. Manufacturing: What Does the Evidence Tell Us?', Journal of Economic Literature, 33, pp. 132-63.

Jans, J.H. and H.H.B. Vedder (eds) (2008), European Environmental Law 3rd edn, Groningen: Europa Law Publishing.

Jansen, N. and R. Michaels (2008), 'Beyond the State? Rethinking Private Law: Introduction to the Issue', American Journal of Comparative Law, 56, pp. 527-39.

Johnston, J.S. (1995), 'Bargaining under Rules versus Standards', Journal of Law, Economics and Organization, 11, pp. 256 and following.

Johnston, J.S. (2000), 'The Law and Economics of Environmental Contracts', in K. Deketelaere and E. Orts (eds), Environmental Contracts: Comparative Approaches to Regulatory Innovation in the United States and Europe, The Hague: Kluwer Law International, pp. 271 and following.

Johnston, J.S. (2008), 'Climate Change Confusion and the Supreme Court: The Misguided Regulation of Greenhouse Gas Emissions under the Clean Air Act', Notre Dame Law Review, 84 (1), pp. 1-74.

Kolstad, C.D. and Y. Xing (2002), 'Do Lax Environmental Regulations Attract Foreign Investment?', Environmental \& Resource Economics, 21, p. 1.

Lavrysen, L. (1995), 'Judicial Responses in the Nineties to Dutch (and German) Shipments of Waste to Belgium in the Eighties', Maastricht Journal of European and Comparative Law, 2 (3), pp. 219-43.

Legrand, P. (2008), 'Antivonbar', Journal of Comparative Law, 1 (1), pp. 13-40.

Lemke, P. (2006), 'Dimensions and Mechanisms of Global Climate Change', in G. Winter (ed.), Multi-level Governance of Global Environmental Change: Perspectives from Science, Sociology and the Law, Cambridge: Cambridge University Press, pp. 37-66.

Macrory, R. (2005), 'The Enforcement of EU Environmental Law: Some Proposals for Reform', in R. Macrory (ed.), Reflections on 30 Years of EU Environmental LawA High Level of Protection?, Groningen: Europa Law Publishing, pp. 385-95.

Macrory, R. (2006), 'Compliance Mechanisms in the European Community - A Global Model', in International Comparative Legal Guide to Environmental Law, London: Global Legal Group, pp. 1-4.

Macrory, R. (ed.) (2008), Regulation, Enforcement and Governance in Environmental Law, London: Cameron May.

Mander, J. (2003), 'Intrinsic Negative Effects of Economic Globalization on the Environment', in J.G. Speth (ed.), Worlds Apart: Globalization and the Environment, Washington: Island Press, pp. 109-29. 
Martens, P. (2007), 'Duurzame Ontwikkeling in een Mondialiserende Wereld', Humanistiek, 8 (29), pp. 39-47.

Martens, P. and D. Zywietz (2006), 'Rethinking Globalization: a Modified Globalization Index', Journal of International Development, 18, pp. 331-50.

Nollkaemper, P.A. (1998), 'How Public International (Environmental) Law Can Furnish a Rule of Decision in Civil Litigation', Tijdschrift voor Milieuaansprakelijkheid (Environmental Liability Review), pp. 3-11.

Nollkaemper, P.A. (2006), 'Responsibility of Transnational Corporations in International Environmental Law: Three Perspectives', in G. Winter (ed.), Multilevel Governance of Global Environmental Change: Perspectives from Science, Sociology and the Law, Cambridge: Cambridge University Press, pp. 179-99.

Nollkaemper, P.A. (2008), 'Cluster-Litigation in Cases of Transboundary Environmental Harm', in M. Faure and Y. Song (eds), China and International Environmental Liability. Legal Remedies for Transboundary Pollution, Cheltenham, UK and Northampton, MA, USA: Edward Elgar, pp. 11-37.

Ogus, A.I. (ed.) (2004), Regulation: Legal Form and Economic Theory, Oxford: Hart Publishing.

Peeters, M. (2008), 'The Joint Governance of Transboundary River Basins: Some Observations on the Rule of Law', in M. Faure and Y. Song (eds), China and International Environmental Liability: Legal Remedies for Transboundary Pollution, Cheltenham, UK and Northampton, MA, USA, Edward Elgar, pp. 192-224.

Peeters, M. and K. Deketelaere (eds) (2006), The EU Climate Change Policy. The Challenge of New Regulatory Initiatives, Cheltenham, UK and Northampton, MA, USA: Edward Elgar.

Porter, G. (1999), 'Trade Competition and Pollution Standards: "Race to the Bottom" or "Stuck at the Bottom"?', The Journal of Environment and Development, 8 (2), pp. 133-51.

Porter, M. and C. Van den Linde (1995), 'Towards a New Conception of the Environment-Competitiveness Relationship', Journal of Economic Perspectives, 9 (4), pp. 97-118.

Prechal, S. and M. de Leeuw (2007), 'Dimensions of Transparency: The Building Blocks for a New Legal Principle?', Review of European Administrative Law, pp. 51-62.

Prechal, S. and M. de Leeuw (2008), 'Transparency: A General Principle of EU Law?', in U. Bernitz, J. Nergelius and C. Cardner (eds), General Principles of European Community Law in a Process of Development, 2nd edition, The Hague: Kluwer Law International, pp. 207-48.

Prévost, M.D. (2009), Balancing Trade and Health in the SPS Agreement: The Development Dimension, Nijmegen: Wolf Legal Publishers.

Princen, S.B.M. (2002), 'The California Effect in the Transatlantic Relationship', dissertation, Utrecht University, the Netherlands.

Rest, A. (1997), 'International Environmental Liability Law before German Courts', Tijdschrift voor Milieuaansprakelijkheid (Environmental Liability Review), pp. 116-22.

Revesz, R. (1992), 'Rehabilitating Interstate Competition: Rethinking the Race-to-thebottom Rationale for Federal Environmental Regulation', New York University Law Review, 67, pp. 1210-54.

Revesz, R. (1996), 'Federalism and Interstate Environmental Externalities', University of Pennsylvania Law Review, 144, pp. 2341-416. 
Revesz, R.L. (1997), 'Federalism and Environmental Regulation: Lessons for the European Union and the International Community', Virginia Law Review, 83, pp. 1331 and following.

Romano, C.P.R. (ed.) (2000), The Peaceful Settlement of International Environmental Disputes: A Pragmatic Approach, London: Kluwer Law International.

Sand, P.H. (2006), 'Global Environmental Change and the Nation State: Sovereignty Bounded?', in G. Winter (ed.), Multi-level Governance of Global Environmental Change: Perspectives from Science, Sociology and the Law, Cambridge: Cambridge University Press, pp. 519-38.

Sands, P. (2000), 'Environmental Protection in the Twenty-first Century: Sustainable Development and International Law', in R.L. Revesz, P. Sands and R.B. Stewart, Environmental Law, the Economy and Sustainable Development. The United States, the European Union and the International Community, Cambridge: Cambridge University Press, pp. 369-409.

Sands, P. (ed.) (2003), Principles of International Environmental Law, 2nd edition, Cambridge: Cambridge University Press.

Schäfer, H.B. (2006), 'Rules versus Standards in Rich and Poor Countries: Precise Legal Norms as Substitutes for Human Capital in Low-Income Countries', Supreme Court Economic Review, pp. 113-34.

Scott, J.S. (ed.) (2007), The WTO Agreement on Sanitary and Phytosanitary Measures, Oxford: Oxford University Press.

Seerden, R.J.G.H. (ed.) (2007), Administrative Law of the European Union, its Member States and the United States: A Comparative Analysis, 2nd edition, Antwerp: Intersentia.

Slovic, P., B. Fischhoff and S. Lichtenstein (2000), 'Rating the Risks', in P. Slovic (ed.), The Perception of Risk, London: Earthscan, pp. 104-20.

Smits, J. (1998), 'A European Private Law as a Mixed Legal System: Towards a Ius Commune Through the Free Movement of Legal Rules', Maastricht Journal of European and Comparative Law, 5, p. 328.

Speth, J.G. (ed.) (2003), Worlds Apart: Globalization and the Environment, Washington: Island Press.

Stewart, R.B. and J.B. Wiener (eds) (2003), Reconstructing Climate Policy: Beyond Kyoto, Washington: AEI Press.

Temmink, H. (2000), 'From Danish Bottles to Danish Bees: The Dynamics of Free Movement of Goods and Environmental Protection - A Case Law Analysis', in H. Somsen et al. (eds), The Yearbook of European Environmental Law, 1, Oxford: Oxford University Press, pp. 73 and following.

Tiebout, C. (1956), 'A Pure Theory of Local Expenditures', Journal of Political Economy, 64, pp. 416-24.

Trebilcock, M.J. and R. Winter (1997), 'The Economics of Nuclear Accident Law', International Review of Law and Economics, 17, pp. 215-43.

Van Calster, G. (2002), 'Public Environmental Law in the European Union', in R.J.G.H. Seerden, M.A. Heldeweg and K.R. Deketelaere (eds), Public Environmental Law in the European Union and the United States, The Hague: Kluwer Law International, pp. 465-515.

Van Dam, C. (2007), 'European Tort Law and the Many Cultures of Europe', in T. Wilhemsson (ed.), Private Law and the Cultures of Europe, The Hague: Kluwer Law International, pp. 53-76.

Van den Bergh, R. (2000), 'Economic Criteria for Applying the Subsidiary Principle in European Environmental Law', in R.L. Revesz, P. Sands and R. Stewart (eds), 
Environmental Law, the Economy and Sustainable Development: The United States, the European Union and the International Community, Cambridge: Cambridge University Press, pp. 80-95.

Van den Borre, T. (2007), 'Shifts in Governance in Compensation for Nuclear Damage, 20 Years after Chernobyl', in M. Faure and A. Verheij (eds), Shifts in Compensation for Environmental Damage, Vienna: Springer, pp. 261-311.

Van den Bossche, P. and D. Prévost (2005), 'The Agreement on the Application of Sanitary and Phytosanitary Measures', in P. Macrory, A. Appleton and M. Plummer (eds), The World Trade Organization: Legal, Economic and Political Analysis, Vienna: Springer, pp. 231-70.

Van Der Linde, M. (2000), 'Globalization and the Right to a Healthy Environment: The South African Experience', East African Journal of Peace \& Human Rights, 6 (2), pp. 253-67.

Van Ierland, E.C., J. Gupta and M.T.J. Kok (eds) (2003), Issues in International Climate Policy. Theory and Policy, Cheltenham, UK and Northampton, MA, USA: Edward Elgar.

Verheij, A. (2007), 'Shifts in Governance: Oil Pollution', in M. Faure and A. Verheij (eds), Shifts in Compensation for Environmental Damage, Vienna: Ectil, pp. 133-95.

Verwey, M. (2000), 'Why is the River Rhine Cleaner than the Great Lakes (Despite Looser Regulation)?', Law \& Society Review, 34 (4), pp. 1007-54.

Vogel, D. (ed.) (1995), Trading Up: Consumer and Environmental Regulation in a Global Economy, Cambridge, MA: Harvard University Press.

Vogel, D. (2004), 'Trade and the Environment in the Global Economy: Contrasting European and American Perspectives', in N.J. Vig and M.G. Faure (eds), Green Giants? Environmental Policies of the United States and the European Union, Cambridge: MIT Press, pp. 231-52.

Von Wilmowsky, P. (1993), 'Waste Disposal in the Internal Market: The State of Play after the ECJ's Ruling on the Walloon Import Ban', Common Market Law Review, 30, pp. 541 and following.

Vos, E. (2000), 'Food Safety Regulation in the Aftermath of the BSE Crisis', Journal of Consumer Policy, 23, pp. 231-49.

Wang, H. (2007), 'Shifts in Governance in the International Regime of Marine Oil Pollution Compensation: Legal History Perspective', in M. Faure and A. Verheij (eds), Shifts in Compensation for Environmental Damage, Vienna: Ectil, pp. 197-241.

Wessel, R. and J. Wouters (2008), 'The Phenomenon of Multi-level Regulation: Interactions between Global, EU and National Regulatory Spheres', in A. Follesdal, R.A. Wessel and J. Wouters (eds), Multi-level Regulation and the EU: The Interplay between Global, European and National Normative Processes, Leiden: Martinus Nijhoff, pp. 9-47.

Whytock, C.H.R.A. (2007), 'Transnational Law, Domestic Courts, and Global Governance', University of Utah Legal Studies Research Paper Series, no. 07-05, available at http://ssrn.com/abstracts=976274.

Wiener, J.B. (2004), 'Convergence, Divergence, and the Complexity in U.S. and European Risk Regulation', in N.J. Vig and M.G. Faure (eds), Green Giants? Environmental Policies of the United States and the European Union, Cambridge: MIT Press, pp. 73-109.

Winter, G. (eds) (2006), Multi-level Governance of Global Environmental Change: Perspectives from Science, Sociology and the Law, Cambridge: Cambridge University Press. 
Wirth, D.A. (2004), 'The President, the Environment, and Foreign Policy: The Globalization of Environmental Politics', Journal of Land, Resources \& Environmental Law, 24 (3), pp. 393-407.

Wirth, D.A. (2007), 'Globalization and the Environment: Why All the Fuss?', Boston College Law School Faculty Papers, 189 (available at http://lsr.nellco.org/bc/bclsfp/ papers/189).

Zander, J. (2009), 'Different Kinds of Precaution. A Comparative Analysis of the Application of the Precautionary Principle in Five Different Legal Orders', dissertation, Maastricht University, April. 